of limestone may occur in addition, but the calcite mudstone seems to be an invariable constituent and the original knoll topography is moulded in it. This rock is one of the rare autochthonous limestones in a succession which is essentially allochthonous. It apparently accumulated in a quiet environment as a chemical or biochemical precipitate which retained its original and irregular mound-covered surface because of the absence of currents which elsewhere were sorting and distributing the constituents of the clastic limestones. That this surface was often extremely complex can be and has been demonstrated by Dr. Parkinson in the Clitheroe and Whitewell districts of Bowland. I find it very difficult to see in what way these limestones are different from the "unbedded reef-limestone", discussed by Dr. Bond, the "main body" of which is "invariably pale-coloured unfossiliferous calcite mudstone" (Bond, op. cit., p. 274). Also, since he agrees that the Grassington and Bowland knolls are knolls of original deposition $I$ do not understand his difficulty in seeing "how the unbedded reef limestone (of Cracoe) could have accumulated as distinct mounds" (Bond, op. cit., p. 277). The same rock type is concerned in all three cases. Is it not possible that there are original knolls at Cracoe and that some of the dips in the limestones are in part depositional and in part tectonic in origin?

I would also venture to suggest that there may be difficulty in establishing an original knoll form where the covering rock is also a limestone and behaves similarly under erosion. Thus, at Scaleber and Malham it seems to be necessary to distinguish between knolls of three distinct ages. Firstly, the original knoll topography of the calcite mudstones which was quickly covered by limestones of $D_{1}$ and $D_{2}$ age ; secondly, the erosional knolls which were formed when these limestones were cut into by Pre-Namurian erosion and which, as Dr. Hudson has stated on numerous occasions, have no affinity with " reef-knolls". Nevertheless, they often contain one or more of the original knolls. Thirdly, the ercsional knolls of the present day which are being produced by the removal of the Bowland shale cover and by further erosion of the erosional knolls of the second age.

Finally, I would suggest caution in basing any reconstruction of conditions of deposition on the evidence of " tufa ". Work on which I have been engaged for some time suggests that some at least of this "tufa " is of secondary origin.
Department of Geology,
THE UNIVERSITY, NOTTINGHAM.
29 th September, 1950.

W. W. BLACK.

\title{
NEW "SPECIES"
}

SIR,--The last paragraph of Mr. J. L. Begg's recent paper (1950) on Girvan trilobites contains a remarkable acknowledgment " . . . to Dr. A. E. Trueman for the suggestion that, meantime, this example [of Teratorhynchus sp.] should not be given a specific determination ". The specimen in question is incomplete and poorly preserved. That Mr. Begg should have considered erecting a new species upon a study of this material is a matter of some interest to geologists, representing as it does a very common approach to descriptive palaeontology. Recent publications by Burma (1948), Jeletzky (1950), Simpson (1941), and Simpson and Roe (1939), have drawn attention to the need for a more conservative treatment of questions of specific differentiation and at the same time to various "blind-spots" in some palaeontological work.

The possibilities of variation between closely related individuals or groups of individuals in an animal population are well-known and limited in number, being due to the presence of :-

1. Subspecies, usually mutually exclusive geographically, but capable of intermingling and replacement. It is worth noting that lateral (geographic) range of some animals is much underestimated by many palaeontologists. To some extent this may be attributed to a regrettable 
tendency towards isolationism or nationalism among workers in this field (Jeletzky, 1950).

2. Varieties in time, caused by the normal processes of selective change and serving as links between conventionally separable "species".

3. Variants within populations (and hence included in both (1) and (2) above) due to natural dispersion relative to a mean, to the presence of all growth stages, and to pathological causes (Aitken and McKerrow, 1948 ; Kaufmann, 1933).

4. Sexual dimorphism and polymorphism within populations (included in 1-3 above).

When these factors are taken into account it becomes evident that any random sample taken from a population, particularly if the sample is a very small one, may show considerable variation from the mean for any particular characteristic or attribute. In view of the pioneer work carried out in this field by, for example, Carruthers, O. T. Jones, and Trueman and Weir, one would have expected British workers to have reached an advanced stage of consciousness of the problems involved, especially in view of the recent rapid development of statistical methods designed for zoological application. So far from this being the case, however, much palaeontological descriptive work seems still to be concerned more with the proliferation of generic and specific names than with any desire to get a clearer picture of past animal communities. The records in such cases are often entirely useless to other workers who are not able to examine the actual specimens and the matrices in which they are contained. In particular, the practice of erecting new specific names on the basis of single, often incomplete and badly preserved, specimens can only be defended when applied to cases where early growth stages are retained in the "mature" individual or are derivable from the individual (as, for example, in graptolites, corals, and to a lesser extent brachiopods), and thus approximate the characters of a larger sample of the actual population.

In general (assuming that one of the objects of palaeontology is to assist in the development of a palaeoecological appreciation in its broadest sense) all descriptions should be based on samples capable of expression as better or worse approximations to the real formerly existing animal population. The degree of approximation can easily be recorded mathematically and gives an estimate within exact limits of the amount and directions of variability shown by members of a population, or the proportions within a population characterized by the presence or absence of certain attributes. Work along such lines will naturally tend to diminish the importance of the holotype in taxonomy and to substitute for it the group of syntypes-the "hypodigm" of Simpson. (It is, however, not at all the same thing to assemble such a group and merely to record a series of observed ranges for selected variates, since the observed range by itself is meaningless unless supplemented by estimates of dispersion, variability, etc.)

Finally, in addition to an estimation of the true population-characters the palaeontologist must always be considering the effect of environmental control in determining faunal assemblages and associations. How rarely is any indication given, in the general run of palaeontological work, of the mode of occurrence of the fossils, their relative abundance and relations with the prevailing sedimentary regime, their distribution in position of growth or as random assemblages. Yet all these are factors which are usually determinable without much difficulty and would serve as invaluable raw data for workers in similar and other closely related fields, such as palaeoecology and palaeogeography, especially where these are at the stage of synthesis. It is very desirable, if palaeozoological investigations are not to be progressively buried beneath the weight of their own accumulating nomenclature, that some sort of uniformity of treatment should be recognized at least as an ideal. The most valuable elements in such a scheme would be an increasing use of populationsamples as the basis for specific identification rather than the rigid adherence 
to the holotype concept, and a more general agreement and standardization in the use of the infraspecific units-subspecies, variety, and variant.

\section{SeDgwick Museum, CAMBridge.} September, 1950.

\section{REFERENCES}

Aitken, W. G., and MCKerrow, W. S., 1948. Rhynchonellids of the Boueti Bed of the Great Oolite Series of Langton Herring, in Dorset : A Study in Variation. Geol. Mag., lxxxv, 19-32.

BeGG, J. L., 1950. New Trilobites from Girvan. Geol. Mag., lxxxvii, 285-291. Burma, B. H., 1948. Studies in Quantitative Palaeontology : I. Journ. Pal., $22,725-761$.

JeLETZKY, J. A., 1950. Some nomenclatorial and taxonomic problems in palaeozoology. Journ. Pal., 24, 19-38.

KaUfmanN, R., 1933. Variationstatistische Untersuchungen über die "Artabwandlung " und "Artumbildung" an der Oberkambrischen Trilobitengattung Olenus Dalman. Abhandlung aus dem geologischpaläontologischen Institut der Universität Greifswald, x, 1-54.

Simpson, G. G., 1941. Range as a zoological character. Amer. Jour. Sci., 239, 785-804.

and ROE, A., 1939. Quantitative Zoology. McGraw-Hill.

\section{SUPPOSED FOSSIL FROM THE CHARNIAN}

SIR,-In the course of a study of the Pre-Cambrian rocks of Leicestershire a tubular object, resembling the kind of tube made by burrowing worms, was discovered in the Brand Series of Swithland Wood, Charnwood Forest, near the "Brand" on the east side of the Charnian dome.

The rocks of Swithland Wood and the near-by grounds of the "Brand" are made up of the so-called Brand ash and conglomerate. Quartzite is extremely abundant, interbedded with chloritic and slaty material; the specimen was found in the interbedded slaty material.

The object is approximately $18 \mathrm{~mm}$. long, about $2 \mathrm{~mm}$. wide, tubular, the substance of the central space of the tube being composed essentially of vugh-like crystalline quartz. The tube shows nodular thickening or transverse ridges on its upper surface, the ridges about $3 \mathrm{~mm}$. apart. The material composing the object is chlorite.

Lapworth (Watts, 1947, p. 104) ${ }^{1}$ noted the lithological resemblance of the Cardingmill Grit, a member of the Synalds Group of the Stretton Series of the Longmynd, to the lower part of the Brand Series. So-called worm tracks and burrows have been reported from the Synalds Group in the Longmynd and Lapworth (Watts, op. cit., p. 104) also found a worm burrow in Bradgate Park, Charnwood Forest, about 1 to $1 \frac{1}{2}$ miles south of the "Brand". From the same locality other specimens have since been reported by Bennett and Rhodes (Watts, op. cit., p. 104).

Nevertheless, some of the supposed markings found in the Pre-Cambrian, such as the so-called ripple-marks of the Longmyndian have lately been considered secondary deformation or related phenomena, and the "ripplemarks " have been termed shear and pressure effects. Similarly the so-called worm boring discussed here may have been of inorganic origin, and the external ridging of the tube may be of a fortuitous nature.

The specimen has been given to the Geological Survey Museum and is registered 84592.

UNIVERSTTY OF CINCINNATI,

Gerald M. Friedman.

\section{Cincinnati 21}

Онго.

20th October, 1950.

1 WATTS, W. W., 1947. Geology of the Ancient Rocks of Charnwood Forest, Leicestershire. Leicester Literary and Philosophical Society. 